\title{
EARTHQUAKE RESPONSE OF AN OPEN-TYPE WHARF WITH A PNEUMATIC CAISSON FOUNDATION
}

\author{
DAISUKE SHIBATA ${ }^{1} \&$ TAKASHI NAGAO ${ }^{2}$ \\ ${ }^{1}$ Japan Port Consultants Ltd., Japan \\ ${ }^{2}$ Research Center for Urban Safety and Security, Kobe University, Japan
}

\begin{abstract}
An open-type wharf with a pneumatic caisson foundation has strong earthquake resistance because of its high rigidity. Construction of wharves with stronger seismic resistance and a larger planned depth is indispensable to accommodate ever-increasing larger vessels. Considering this trend and strong earthquake resistance, open-type wharves with a pneumatic caisson foundation will be widely applied in the future. Consequently, it is necessary to establish a practical design method of the wharf. Existing practical earthquake resistant design methods for an open-type wharf with a steel pipe pile foundation follow the below-mentioned procedure: (i) To calculate acceleration response spectra at the position of $1 / \beta$ below the virtual ground surface by means of a one-dimensional earthquake response analysis of the ground. Here, the virtual ground surface means a $1 / 2$ gradient face in between the slope and the seabed. $\beta$ is a pile characteristic value; (ii) To calculate response acceleration corresponding to the natural period of the wharf. Here, the damping constant is 20\%; (iii) To divide the response acceleration by gravity acceleration to obtain seismic coefficients; and (iv) To calculate inertial force using the seismic coefficients and verify the stability of the structure. To follow the design procedure described above may be appropriate. However, the difference in the rigidity of foundation between the two structural types should be considered. The authors conducted two-dimensional finite element earthquake response analyses, modelling both open-type wharves with pneumatic caissons and soil layers, and discussed their earthquake responses. As a result of this study, the earthquake response of the wharf with pneumatic caissons is different from that on a steel pipe pile foundation. The optimum evaluation positions of acceleration response spectra have proved to be foundation bottom levels, and the optimum damping constant for the evaluation of response acceleration to range from 5-20\%.

Keywords: earthquake resistant design, open-type wharf, acceleration response, damping constant.
\end{abstract}

\section{INTRODUCTION}

The construction method of a pneumatic caisson foundation is to immerse caissons by feeding high-pressure air into their lowest part, and carrying out extraction while preventing invasion of underground water. As an advantage of this method, excellent earthquake proof can be named thanks to the high rigidity of the body and high supporting structure against loads in the vertical as well as horizontal directions. In Japan the method of pneumatic caisson foundation is applied mainly to the foundations of bridges and vertical shafts in shield tunnels and there are few applications to port and harbour works as a foundation of an open-type wharf. This appears to be largely because a design method for a wharf with pneumatic caisson foundation is yet to be established. Meanwhile, as for the situational change in the expectations of mooring facilities, world trend of constructing larger vessels has been requiring more deep-water and more earthquake resistant mooring facilities. This situation change will increasingly promote construction of wharves with pneumatic caisson foundations, urging prompt establishment of the corresponding design method. The design method for wharves in the Japanese Technical Standards for Port Facilities is established focusing on wharves on steel pipe pile foundations. As the design method of a wharf with a pneumatic caisson foundation, to follow the method established in the said standards seems to be basically appropriate. There is, however, a big difference in the rigidity between the steel pipe pile foundation and the caisson foundation. Consequently, wharves on steel pipe 
pile foundations and wharves with pneumatic caisson foundations will presumably have behaviour different from each other at the time of an earthquake. Establishment of a design method for a wharf with a pneumatic caisson foundation needs to first clarify the seismic behavioural difference, thereby establishing a method that reflects the behaviour of the said wharf at the time of an earthquake. This study will discuss the behaviour at an earthquake of a wharf with a pneumatic caisson foundation by a two-dimensional non-linear finite element analysis.

\section{EARTHQUAKE-RESISTANT DESIGN METHOD FOR WHARF ON STEEL PIPE PILE FOUNDATION}

\subsection{Earthquake-resistant design method in Japan [1]}

This section will address the earthquake-resistant design method for a wharf on a steel pipe pile foundation stipulated in the Japanese Technical Standards for Port Facilities. The Kobe earthquake in 1995 triggered adoption of using two-stage earthquake ground motions as the input motions in designing earthquake-resistant infrastructure facilities in the country. The above-mentioned standards also introduced the method of two-stage earthquake ground motions. The design seismic ground motion pursuant to the port standards is characterized by the requirement of utilizing site dependent motions. Designers engaged in the designing work are required to establish seismic ground motions that reflect the amplifying characteristics of the motions occurring from the seismic bedrock to the engineering bedrock on each of the sites for constructing the mooring facilities. Accordingly, different seismic ground motions are established by means of a time history waveform format. This study focuses on Level-one earthquake ground motions, which presumably occur with such degree of frequency as can be experienced during the period of conducting design work, out of the two-stage ground motions. The forthcoming paragraphs will deal with the method of earthquake-resistant design specifically for Level-one seismic ground motions. The wharf being addressed here has a rigid-frame structure as shown in Fig. 1, and the one on the steel pipe pile foundation has a structure with its mass concentrated upon the superstructure. The earthquake-resistant design figures out the safety margin of the structural components while the superstructure is subjected to static inertial force. The inertial force can be obtained by multiplying a seismic coefficient with the mass, and the seismic coefficient is calculated by the following process:

(i) Earthquake responses at the position of $1 / \beta$ below the virtual ground surface are obtained by means of the one-dimensional earthquake response analysis that models the subsoil of the central part of the superstructure. The virtual ground surface means a $1 / 2$ gradient face in between the slope and the elevation of the seabed soil. $\beta$ is a parameter called a pile characteristic value that appears in beam deflection curve on the elastic foundation and is obtained [2] from eqn (1) below. Here, the reason why the position to evaluate acceleration response spectra is set at $1 / \beta$ below the virtual ground surface is in order to regard $1 / \beta$ as the fixed point of the pile pursuant to the deflection theory of the beam on the elastic foundation, and to take into consideration the pile-ground interaction in the range from the seabed to the fixed point

$$
\beta=\sqrt[4]{\frac{k_{C H} D}{4 E I}},
$$

where $\beta$ : characteristic value of the pile $\left(\mathrm{cm}^{-1}\right), k_{C H}$ : reaction coefficient of subsoil in cross direction $\left(\mathrm{N} / \mathrm{cm}^{3}\right), D$ : pile width $(\mathrm{cm}), E I$ : bending rigidity of the pile $\left(\mathrm{N} \cdot \mathrm{cm}^{2}\right)$. 


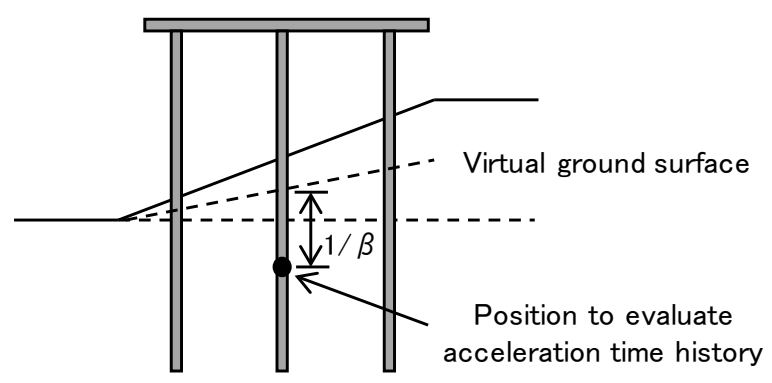

Figure 1: Image of open-type wharf on vertical piles.

(ii) Acceleration response spectra with a damping constant of $20 \%$ are obtained from the resulting earthquake response. The reason why this value is set as the damping constant is in order to evaluate acceleration response spectra by the one-dimensional earthquake response analysis, it is appropriate to set an apparent damping constant that is larger than the damping constant of the structural body at finding the earthquake responses of the superstructure, given the inability to consider the existence of the actual slope or piles in the central part of the wharf [3].

(iii) Maximum response acceleration corresponding to the natural period of the wharf is obtained from the acceleration response spectra, and a seismic coefficient for verification is calculated by dividing the maximum response acceleration by gravity acceleration.

In general, the natural period of a structure is obtained from eqn (2). For a wharf, spring constants are determined on the basis of the rigidity of the foundation and others

$$
T_{s}=2 \pi \sqrt{\frac{W}{g K}}
$$

where $T_{s}$ : natural period of the wharf (s), $W$ : empty weight on one pile line and surcharge at earthquake $(\mathrm{kN}), g$ : gravity acceleration $\left(\mathrm{m} / \mathrm{s}^{2}\right), K$ : spring constant of the wharf $(\mathrm{kN} / \mathrm{m})$.

\subsection{Earthquake-resistant design method in the USA [4]}

This section will describe the earthquake-resistant design method employed in the USA for a wharf on steel pipe piles. US seismic codes are published by American Society of Civil Engineers (ASCE) in terms of ASCE7 Minimum Design Loads for Buildings and Other Structures. ASCE7 stipulates the calculation of Design Earthquake on the basis of the natural period of a structure by using design acceleration response spectra. Here, the design acceleration response spectra are set by taking into account Maximum Considerable Earthquake (MCE) which represents an over 50-year probability of 2\% (return period: 2475 years). US Geological Survey, Department of Interior (USGS) provides two sorts of acceleration response spectra (5\% damping) to MCE by way of an earthquake hazard map: Ss (period: $0.2 \mathrm{sec}$ ) and S1 (period: $1 \mathrm{sec}$ ). Furthermore, site characteristics are classified into six kinds of subsoil on the basis of shear wave velocity, $N$ value and undrained shear strength. Site coefficients of $\mathrm{Fa}$ and Fy corresponding to the respective kinds of subsoil are taken into account. Multiplying the site coefficients of Fa and Fy with Ss and S1 respectively which are read out from the earthquake hazard map will yield the maximum acceleration response values of SM and SM1 that reflect the characteristics of the site. Further multiplication 
of the maximum acceleration response values with $2 / 3$ will give the maximum design response acceleration of SDS and SD1, results which are applied to the earthquake-resistant designing work.

\section{PAST STUDIES ON EARTHQUAKE RESPONSE OF WHARVES}

This section will review past researches made on the seismic response of the superstructure of a wharf.

Kuwabara and Nagao [5] conducted a survey for a wharf with a steel pipe pile foundation in respect to the relation between the seismic effect and the natural period of the wharf by the two-dimensional nonlinear finite element analysis that models the wharf and the subsoil. As a result, they found out that the greater the earthquake ground motion levels are, the longer the natural period of the wharf is. The reasons were attributed to the following phenomenon. Increase in the earthquake ground motion levels will enlarge decrease in the shear modulus of the subsoil, thereby shifting downwards the fixed point of the pile (at $1 / \beta$ below the virtual ground surface). This causes a longer free length of the pile, and a reduced spring constant of the foundation. The authors indicated that these are the causes for the enlargement of natural period.

Okubo et al. [6] conducted a study on the response characteristics at Level-one earthquake for an open-type wharf with a vertical steel pipe pile foundation, to the following effect: A subgrade reaction coefficient that is used to calculate the natural period of the wharf by a frame analysis is mostly set on the basis of $N$ value which results from a standard penetration test without considering the subsoil shear modulus being reduced at the time of an earthquake. The relation between load and displacement of the soil-pile interaction spring obtained from the two-dimensional nonlinear finite element analysis leads to a slope at secant. By establishing a subgrade reaction coefficient obtained from a slope at secant, the natural period of the wharf that considers the reduced shear modulus of the subsoil can be obtained. The obtained natural period of the wharf was reported to be also highly consistent with the equivalent period of the wharf found from the two-dimensional nonlinear finite element analysis. In addition, the maximum acceleration on the crown height of the wharf calculated by one-dimensional earthquake response analysis on the basis of the acceleration response analysis at $1 / \beta$ below the virtual ground surface was reported to deviate to the degree of some $15-70 \%$ of the result obtained from the two-dimensional earthquake response analysis. Enhancement was also reported of the calculation accuracy of the maximum acceleration at the crown height of the wharf by adjusting the position of $1 / \beta$ below the virtual ground surface and on the basis of the subgrade reaction coefficient resulting from the twodimensional nonlinear finite element analysis. This signifies the importance of appropriately considering the reduction in the shear modulus of the subsoil at earthquake when evaluating the seismic behaviour of a wharf.

The above are the examples of researches concerning the wharf on steel pipe piles. As an example of a study on the wharf with caisson foundation, Oishi et al. [7]-[9] conducted a fundamental study on the earthquake response of a wharf with a caisson foundation by carrying out the two-dimensional nonlinear earthquake response analysis modelling the wharf and the subsoil. As a result, the authors pointed out that depending on the applicable conditions, appropriate evaluation of the earthquake response of superstructure can become impossible when design procedures are based on the stipulations for the wharves on steel pipe piles. This is presumably due to the difference in the earthquake response derived from the difference of the rigidity between the steel pipe pile foundation and the caisson foundation. 


\section{EARTHQUAKE RESPONSE OF WHARVES WITH CAISSON FOUNDATIONS}

\subsection{Method of study}

In this research, the three cases of structures were examined, as by Oishi et al. [7]-[9] for a wharf with a pneumatic caisson foundation. Figs 2-4 illustrate wharf structures and analytical models. The lateral area for analysis is set to $100 \mathrm{~m}$ away from the centre of the wharf so as to avoid the effect of reflection wave from the lateral boundary on the wharf. Tables 1-3 show soil parameters. Liquefaction effect is considered for the reclaimed soil layer of Case A only, with the remaining layers being assumed as free from liquefaction. Table 4 shows dimensions such as caisson foundation pitch and caisson foundation diameter of respective wharves. Among those, Case B represents an actually constructed structure. The time of construction, however, is so old as in the 1950s that it was not designed in accordance with the concept in the current Technical Standards for Port Facilities and there is no way of knowing the then applied design concepts, either. Case A and Case $\mathrm{C}$ are the structures being studied taking into account the earthquake ground motions of port facilities on the basis of the design method established for the wharves on steel pipe piles in the current Technical Standards for Port Facilities. These are, however, not actually constructed structures. The examined structures of the three cases, therefore, have different kinds of earthquake performance.

The evaluation method for earthquake response of a wharf with a pneumatic caisson foundation is the two-dimensional nonlinear finite element analysis. Being a nonlinear analysis, it allows evaluation of the time history nonlinear behaviour of soil and structure and the effect of liquefaction for those soil layers potentially exposed to liquefaction. In addition, the analytical method models wharves and surrounding subsoil, thereby enabling evaluation of structure-soil dynamic interaction. In this research, the analytical code FLIP [10] was utilized for the two-dimensional nonlinear finite element analysis. FLIP adopts a multi-spring model [11] as the model to stipulate dynamic deformation characteristics of soil (Fig. 5). This model divides shearing behaviour of soil into plural virtual simple shear springs. Conforming the load-displacement relation of respective springs to a hyperbolic model enables consideration of nonlinear nature of soil material. Here, the hyperbolic model(called HardinDornevich model) is an expression depicting the relation of shear stress and shear strain by means of the two parameters: initial elastic shear modulus and reference strain, as in eqn (3) [12]. The elastic shear modulus of soil in general depends on mean effective confining pressure. With the increase of depth, the mean effective confining pressure will increase and the elastic shear modulus will rise as well. The confining pressure dependency is considered to be proportional to the 0.5 th power of the mean effective confining pressure [13] as shown in eqn (4)

$$
\begin{gathered}
\tau=\frac{G_{0} \gamma}{1+\left|\frac{\gamma}{\gamma r}\right|}, \\
G_{0}=G_{m a}\left(\frac{\sigma_{m}^{\prime}}{\sigma_{m a}^{\prime}}\right)^{m_{G}},
\end{gathered}
$$

where $G_{0}$ : initial shear modulus $\left(\mathrm{kN} / \mathrm{m}^{2}\right), \gamma$ : strain, $\gamma_{r}$ : reference strain $\left(=\tau_{f} / G_{0}\right), \tau_{f}$ : shear strength $\left(\mathrm{kN} / \mathrm{m}^{2}\right), G_{m a}$ : initial shear modulus under reference effective confining pressure $\left(\mathrm{kN} / \mathrm{m}^{2}\right), \sigma_{m a}$ ': reference effective confining pressure $\left(\mathrm{kN} / \mathrm{m}^{2}\right), \sigma_{m}{ }^{\prime}$ : effective confining pressure $\left(\mathrm{kN} / \mathrm{m}^{2}\right), m_{G}$ : parameter indicating dependency on confining pressure $(0.5)$. 


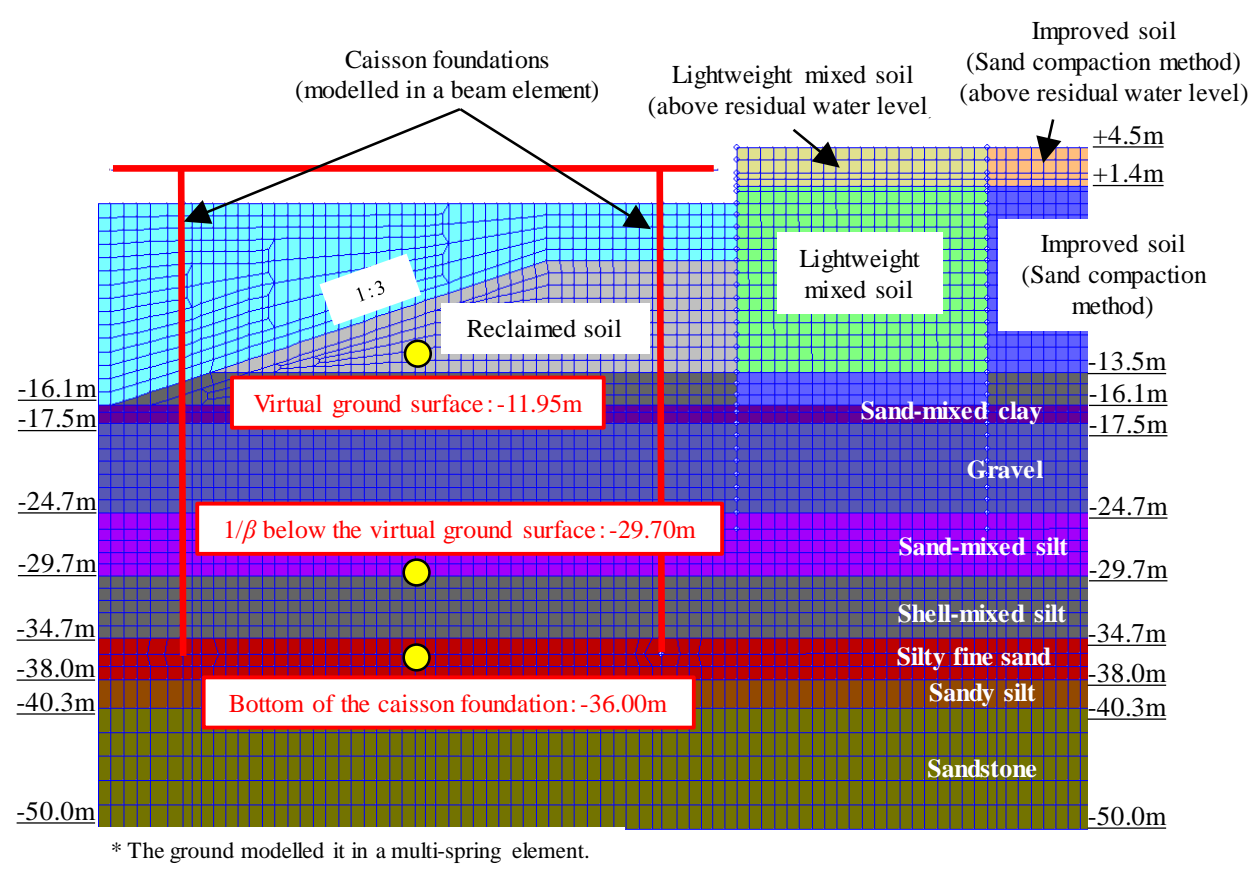

Figure 2: Analytical model (Case A).

Table 1: Soil parameters (Case A).

\begin{tabular}{|c|c|c|c|c|c|}
\hline $\begin{array}{c}\text { Name of } \\
\text { soil layer }\end{array}$ & $\begin{array}{c}\text { Wet } \\
\text { density }\end{array}$ & $\begin{array}{c}\text { Effective } \\
\text { mean stress } \\
\text { at which } \mathrm{G}_{m a}\end{array}$ & $\begin{array}{c}\text { Reference } \\
\text { initial shear } \\
\text { modulus }\end{array}$ & Cohesion & $\begin{array}{c}\text { Shear } \\
\text { resistance } \\
\text { angle }\end{array}$ \\
\cline { 2 - 6 } & $\begin{array}{c}\rho \\
\left(\mathrm{t} / \mathrm{m}^{3}\right)\end{array}$ & $\begin{array}{c}\sigma_{m a}{ }^{\prime} \\
\left(\mathrm{kN} / \mathrm{m}^{2}\right)\end{array}$ & $\begin{array}{c}G_{m a} \\
\left(\mathrm{kN} / \mathrm{m}^{2}\right)\end{array}$ & $\begin{array}{c}c \\
\left(\mathrm{kN} / \mathrm{m}^{2}\right)\end{array}$ & $\begin{array}{c}\varphi \\
\left({ }^{\circ}\right)\end{array}$ \\
\hline $\begin{array}{c}\text { Improved soil } \\
\text { (Sand compaction method) } \\
\text { (above residual water level) }\end{array}$ & 1.8 & 21 & 32720 & 0 & 42 \\
\hline $\begin{array}{c}\text { Improved soil } \\
\text { (Sand compaction method) }\end{array}$ & 1.8 & 98 & 66370 & 0 & 42 \\
\hline $\begin{array}{c}\text { Lightweight mixed soil } \\
\text { (above residual water level) }\end{array}$ & 1.4 & 16 & 34000 & 100 & 0 \\
\hline Lightweight mixed soil & 1.4 & 54 & 34000 & 100 & 0 \\
\hline Reclaimed soil & 2.0 & 98 & 60070 & 0 & 39 \\
\hline Sand-mixed clay & 1.5 & 161 & 24440 & 0 & 30 \\
\hline Gravel & 1.9 & 196 & 96590 & 0 & 42 \\
\hline Sand-mixed silt & 1.7 & 235 & 86560 & 255 & 0 \\
\hline Shell-mixed silt & 1.8 & 261 & 102500 & 301 & 0 \\
\hline Silty fine sand & 1.8 & 287 & 126400 & 0 & 36 \\
\hline Sandy silt & 1.9 & 306 & 112200 & 330 & 0 \\
\hline Sandstone & 1.8 & 342 & 156800 & 0 & 42 \\
\hline
\end{tabular}




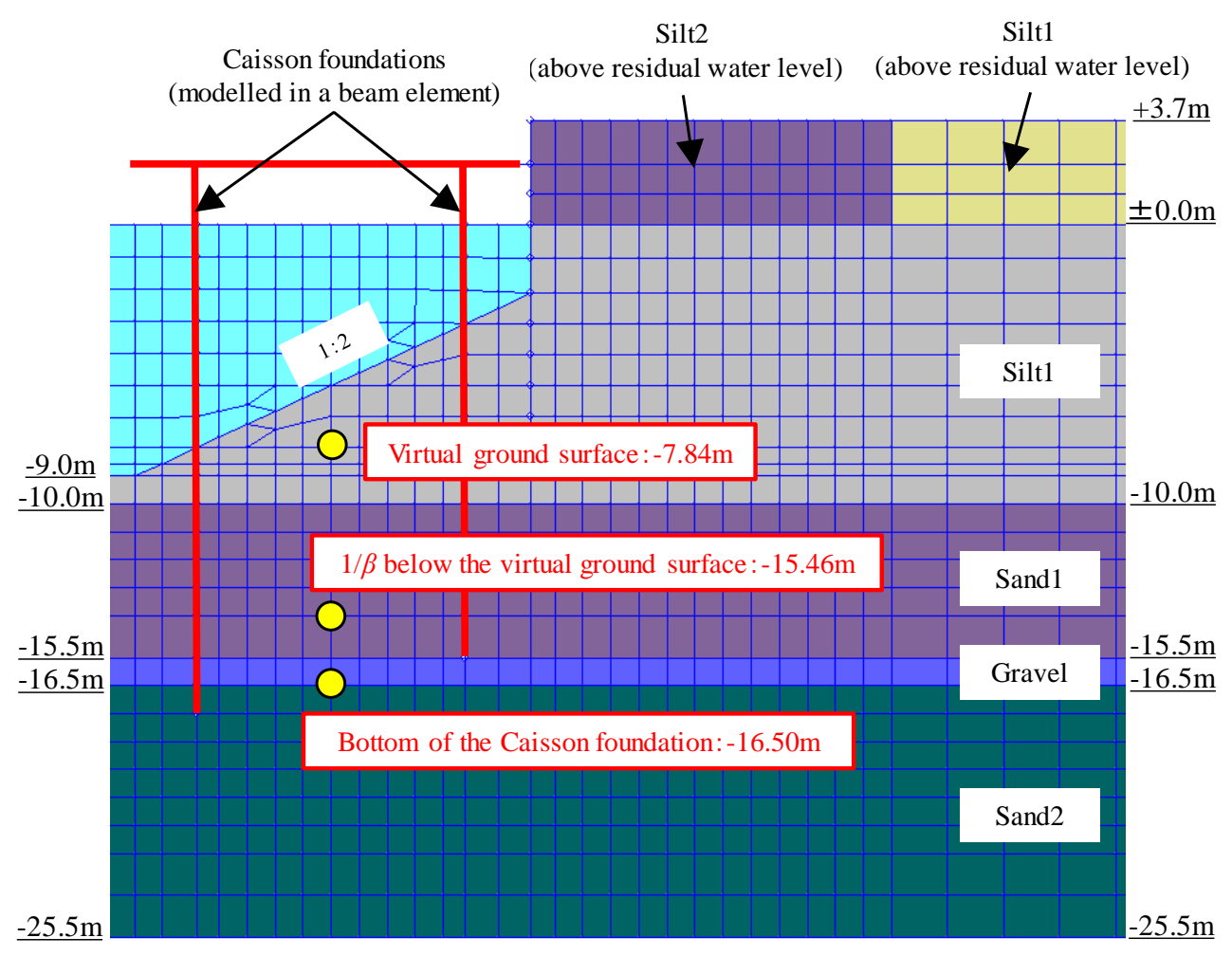

* The ground modelled it in a multi-spring element.

Figure 3: Analytical model (Case B).

Table 2: Soil parameters (Case B).

\begin{tabular}{|c|c|c|c|c|c|}
\hline \multirow{2}{*}{$\begin{array}{c}\text { Name of } \\
\text { soil layer }\end{array}$} & $\begin{array}{c}\text { Wet } \\
\text { density }\end{array}$ & $\begin{array}{c}\text { Effective } \\
\text { mean stress } \\
\text { at which } \mathrm{G}_{m a}\end{array}$ & $\begin{array}{c}\text { Reference } \\
\text { initial shear } \\
\text { modulus }\end{array}$ & Cohesion & $\begin{array}{c}\text { Shear } \\
\text { resistance } \\
\text { angle }\end{array}$ \\
\cline { 2 - 6 } & $\rho$ & $\begin{array}{c}\sigma_{m a}{ }^{\prime} \\
\left(\mathrm{kN} / \mathrm{m}^{3}\right)\end{array}$ & $\begin{array}{c}G_{m a} \\
\left(\mathrm{kN} / \mathrm{m}^{2}\right)\end{array}$ & $\begin{array}{c}c \\
\left(\mathrm{kN} / \mathrm{m}^{2}\right)\end{array}$ & $\begin{array}{c}\varphi \\
\left({ }^{\circ}\right)\end{array}$ \\
\hline $\begin{array}{c}\text { Silt1 } \\
\text { (above residual water level) }\end{array}$ & 1.5 & 28 & 11730 & 0 & 30 \\
\hline Silt1 & 1.5 & 81 & 11730 & 0 & 30 \\
\hline $\begin{array}{c}\text { Silt2 } \\
\text { (above residual water level) }\end{array}$ & 1.5 & 28 & 11730 & 0 & 30 \\
\hline Sand1 & 2.0 & 133 & 88200 & 0 & 40 \\
\hline Gravel & 2.0 & 166 & 125000 & 0 & 42 \\
\hline Sand2 & 2.0 & 166 & 96800 & 0 & 40 \\
\hline
\end{tabular}




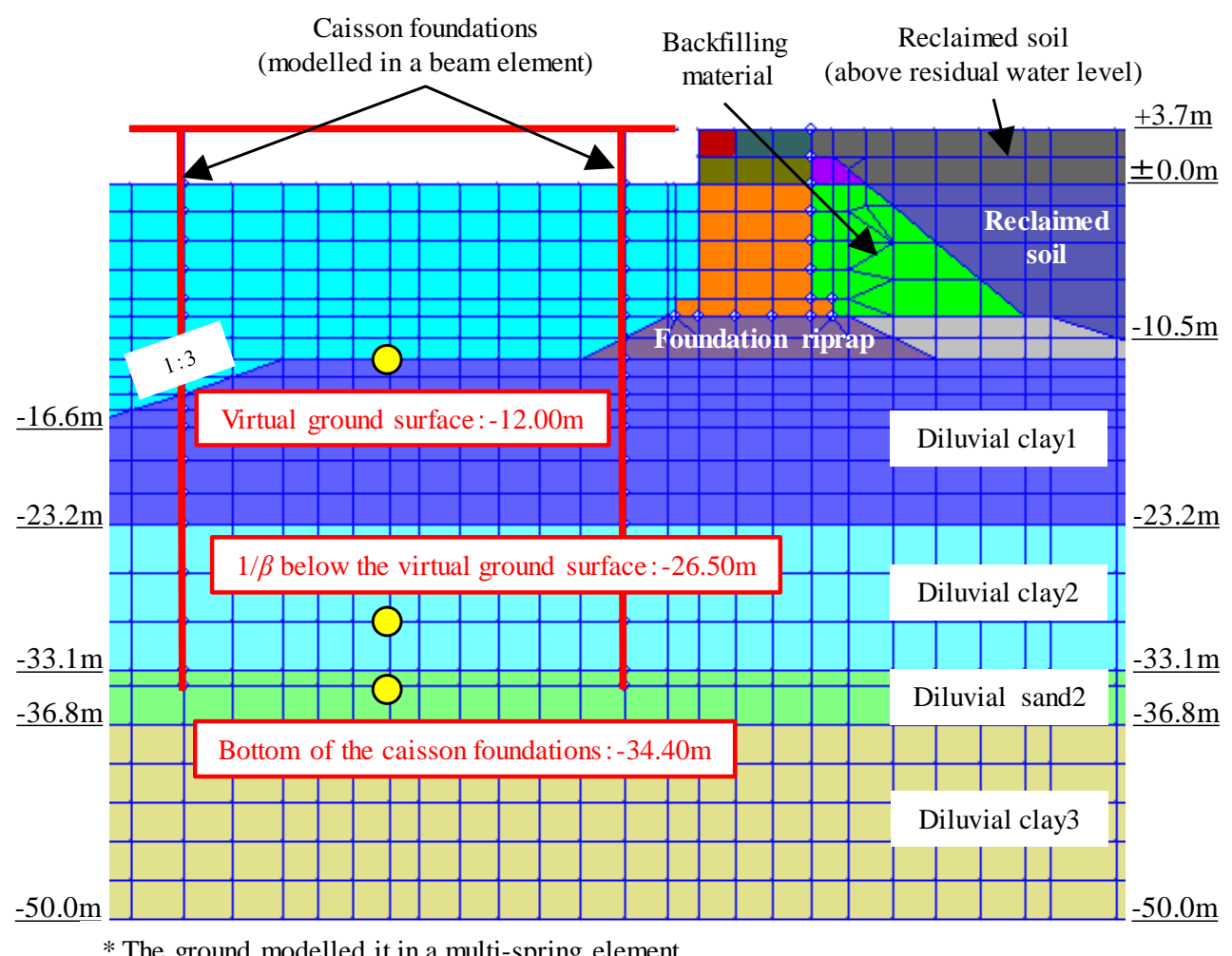

* The ground modelled it in a multi-spring element.

Figure 4: Analytical model (Case C).

Table 3: Soil parameters (Case C).

\begin{tabular}{|c|c|c|c|c|c|}
\hline \multirow{2}{*}{$\begin{array}{l}\text { Name of } \\
\text { soil layer }\end{array}$} & $\begin{array}{c}\text { Wet } \\
\text { density }\end{array}$ & $\begin{array}{c}\text { Effective } \\
\text { mean stress } \\
\text { at which } \mathrm{G}_{m a} \\
\end{array}$ & $\begin{array}{c}\text { Reference } \\
\text { initial shear } \\
\text { modulus } \\
\end{array}$ & Cohesion & $\begin{array}{c}\text { Shear } \\
\text { resistance } \\
\text { angle } \\
\end{array}$ \\
\hline & $\begin{array}{c}\rho \\
\left(\mathrm{t} / \mathrm{m}^{3}\right)\end{array}$ & $\begin{array}{c}\sigma_{m a}{ }^{\prime} \\
\left(\mathrm{kN} / \mathrm{m}^{2}\right)\end{array}$ & $\begin{array}{c}G_{m a} \\
\left(\mathrm{kN} / \mathrm{m}^{2}\right)\end{array}$ & $\begin{array}{c}c \\
\left(\mathrm{kN} / \mathrm{m}^{2}\right)\end{array}$ & $\begin{array}{l}\varphi \\
(\circ)\end{array}$ \\
\hline $\begin{array}{c}\text { Reclaimed soil } \\
\text { (above residual water level) }\end{array}$ & 1.8 & 25 & 20250 & 20 & 30 \\
\hline Reclaimed soil & 1.8 & 89 & 20250 & 20 & 30 \\
\hline Backfilling material & 2.0 & 104 & 180000 & 20 & 40 \\
\hline Foundation riprap & 2.0 & 129 & 180000 & 20 & 40 \\
\hline Diluvial clay1 & 1.7 & 28 & 11450 & 284 & 0 \\
\hline Diluvial clay2 & 1.5 & 75 & 10210 & 284 & 0 \\
\hline Diluvial sand2 & 1.8 & 108 & 150900 & 0 & 39 \\
\hline Diluvial clay3 & 1.8 & 171 & 265200 & 1500 & 0 \\
\hline
\end{tabular}


Table 4: Wharf dimensions.

\begin{tabular}{|c|c|c|c|c|c|}
\hline $\begin{array}{c}\text { Examination } \\
\text { structures }\end{array}$ & $\begin{array}{c}\text { Caisson foundation pitch } \\
\text { in face-line direction } \\
(\mathrm{m})\end{array}$ & $\begin{array}{c}\text { Caisson } \\
\text { foundation } \\
\text { diameter } \\
(\mathrm{m})\end{array}$ & $\begin{array}{c}\text { Virtual ground } \\
\text { surface } \\
(\mathrm{m})\end{array}$ & $\begin{array}{c}1 / \beta \text { below the } \\
\text { virtual ground } \\
\text { surface } \\
(\mathrm{m})\end{array}$ & $\begin{array}{c}\text { Bottom of the } \\
\text { caisson foundation } \\
(\mathrm{m})\end{array}$ \\
\hline CaseA & 20.0 & 6.5 & -11.95 & -29.70 & -36.00 \\
\hline CaseB & 14.0 & 3.7 & -7.84 & -15.46 & -16.50 \\
\hline CaseC & 20.0 & 5.5 & -12.00 & -26.50 & -34.40 \\
\hline
\end{tabular}

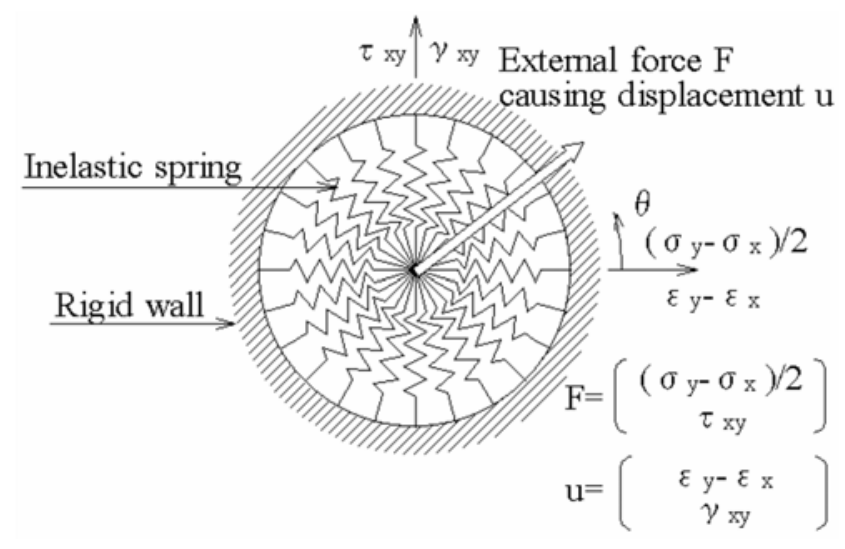

Figure 5: Multi-spring model [11].

Table 5 provides parameters to be used for multi-spring elements, being roughly classified into two kinds: the one that stipulates dynamic deformation characteristics of sand, and the other that defines development of excess pore water pressure of sand. Soil parameters were set according to Morita et al. [14]. The outbreak of an earthquake will cause soil deformation from the land side toward the sea side. Since caisson foundations are laid discretely in the depth direction of the examination structure, there occurs a phenomenon of soil slipping through the foundation components. This effect is taken into account by using a pile-soil interaction spring [15]. The pile-soil interaction spring is an interaction spring element to be inserted in between the joints of the pile (two-dimensional beam element) and the soil (multispring element). Here, the spring strength is evaluated on the basis of relative displacement of the joints of piles and soil by taking into account pile diameter, pile pitch, soil constituting the subsoil near the piles, soil conditions such as unsaturation and/or saturation, load levels and development of liquefaction. Figs 2-4 show structure models in the vicinity of the wharf. The lateral analytical area sets the range up to the sea and land side, each approximately $100 \mathrm{~m}$ away from the front of the wharf such that the behaviour of the lateral boundary will not affect the main body of the structure. The natural periods of the wharf and soil are shown in Table 6. The natural period of the soil is evaluated according to the response of the landside free soil at the time when $\mathrm{S}$ wave enters vertically. The natural period of the wharf is evaluated on the basis of the response value in the condition in which the maximum acceleration is set at $10 \mathrm{Gal}$ such that there will not be nonlinear effects of soil, with input seismic wave being a white-noise, a wave that does not have predominant frequencies. 
Table 5: Analytical parameters required for multi-spring elements.

\begin{tabular}{|c|c|c|}
\hline Classification & \multicolumn{2}{|r|}{ Parameter } \\
\hline \multirow{2}{*}{$\begin{array}{c}\text { Results of } \\
\text { physical testing }\end{array}$} & $\rho_{t}$ & Wet density \\
\hline & $n$ & Porosity \\
\hline \multirow{8}{*}{$\begin{array}{c}\text { Dynamic } \\
\text { deformation } \\
\text { characteristics }\end{array}$} & $\sigma_{m a}^{\prime}$ & Effective mean stress at which $G_{m a}, K_{m a}$ \\
\hline & $G_{m a}$ & Reference initial shear modulus (value in $\sigma_{m}{ }^{\prime}=\sigma_{m a}{ }^{\prime}$ ) \\
\hline & $K_{m a}$ & Reference initial bulk modulus (value in $\sigma_{m}{ }^{\prime}=\sigma_{m a}{ }^{\prime}$ ) \\
\hline & $m G$ & Effective stress dependency under Initial shear modulus $G_{0}$ \\
\hline & $m K$ & Effective stress dependency under Initial volume modulus $K_{0}$ \\
\hline & $\varphi_{f}^{\prime}$ & Shear resistance angle \\
\hline & $C$ & Cohesion \\
\hline & $h_{\max }$ & Upper bound for hysteretic damping factor \\
\hline \multirow{7}{*}{$\begin{array}{c}\text { Liquefaction } \\
\text { characteristics }\end{array}$} & $\varphi_{p}^{\prime}$ & Phase transformation angle \\
\hline & $w 1$ & Parameter regulating whole of liquefaction characteristics \\
\hline & p1 & Parameter regulating first half of liquefaction characteristics \\
\hline & p2 & Parameter regulating second half of liquefaction characteristics \\
\hline & $c 1$ & Parameter regulating lower limit of liquefaction characteristics \\
\hline & S1 & Parameter regulating final states of liquefaction characteristics \\
\hline & Sus & Stress level when steady state is reached \\
\hline
\end{tabular}

Table 6: Natural period of wharf and ground.

\begin{tabular}{|c|c|c|c|c|}
\hline \multirow{2}{*}{$\begin{array}{c}\text { Examination } \\
\text { structures }\end{array}$} & $\begin{array}{c}|c| \\
\text { Open-type wharf }\end{array}$ & \multicolumn{2}{c|}{ Ground } \\
\cline { 2 - 5 } & $\begin{array}{c}\text { Natural frequency } \\
(\mathrm{Hz})\end{array}$ & $\begin{array}{c}\text { Natural period } \\
(\mathrm{s})\end{array}$ & $\begin{array}{c}\text { Natural frequency } \\
(\mathrm{Hz})\end{array}$ & $\begin{array}{c}\text { Natural period } \\
(\mathrm{s})\end{array}$ \\
\hline CaseA & 1.07 & 0.93 & 1.09 & 0.92 \\
\hline CaseB & 1.44 & 0.69 & 1.46 & 0.68 \\
\hline CaseC & 0.63 & 1.59 & 0.47 & 2.13 \\
\hline
\end{tabular}

\subsection{Input earthquake ground motions}

The input earthquake ground motions were set by using the design earthquake ground motion to be applied to Tokyo Port [16]. The predominant frequencies of the earthquake ground motions are $0.86 \mathrm{~Hz}$ and $2.29 \mathrm{~Hz}$. In this study, in order to examine the response of a wharf with a caisson foundation to earthquake ground motions having various predominant frequencies, the second peak in the $2.29 \mathrm{~Hz}$ of the seismic wave of Tokyo Port was cut beforehand, and predominant frequencies varied to $0.2 \mathrm{~Hz}, 1.0 \mathrm{~Hz}$ and $2.0 \mathrm{~Hz}$ were used. Besides, amplitude adjustments were conducted to make all the maximum accelerations become $200 \mathrm{Gal}$. As shown in Table 6, it can be understood that input seismic motion with predominant frequency $1.0 \mathrm{~Hz}$ has close predominant frequency for wharf and the ground of Case A. Acceleration time history and acceleration Fourier spectra of respective waveforms are shown in Fig. 6. 

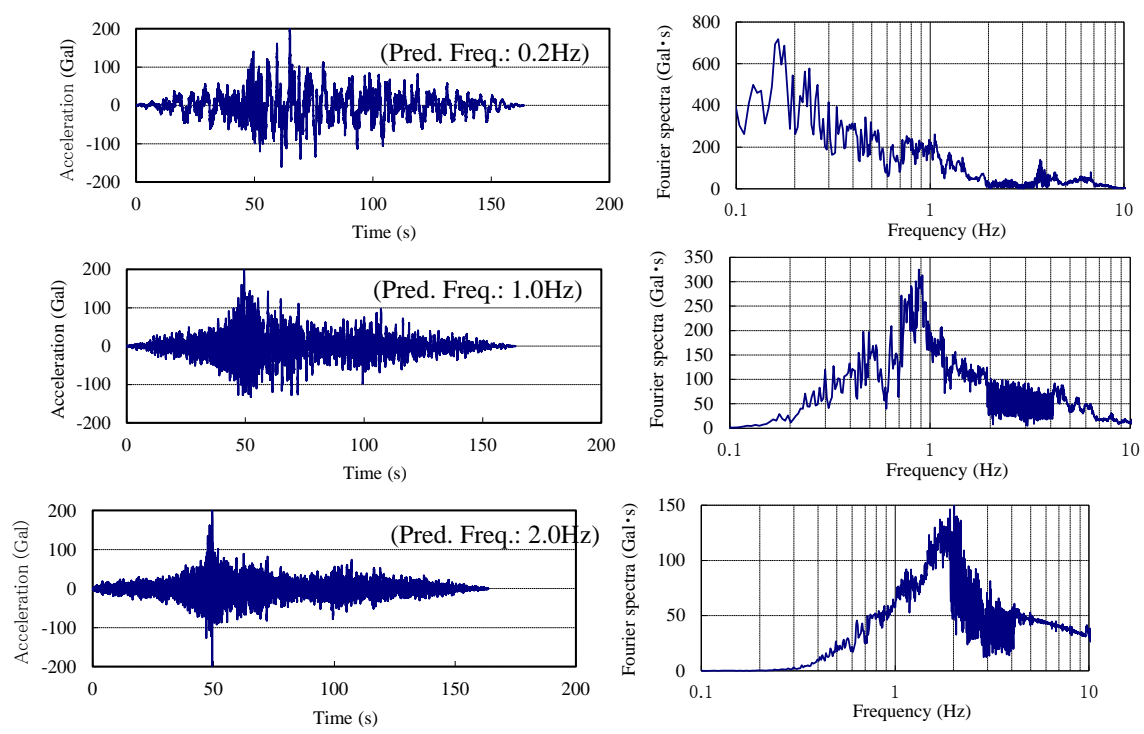

Figure 6: Acceleration time history, acceleration Fourier spectra.

\section{RESULTS OF ANALYSIS}

\subsection{Natural period of wharf}

The natural period of a wharf has been set by taking the reciprocal of the peak frequency read out by arranging the ratios of the acceleration Fourier spectra at the crown height of the wharf to the spectra obtained at: (1) the virtual ground surface; (2) $1 / \beta$ below the virtual ground surface; and (3) the bottom of the caisson foundation. Examples of the acceleration Fourier spectra ratios (Case A_0.2 Hz) are shown in Fig. 7. Red circles are the positions of reading out the peak frequencies. Table 7 shows the results of arranging natural periods of the wharf. Fig. 8 illustrates the depth distribution of shear modulus for each input earthquake ground motion in the central part of the wharf. Here, the blue lines represent initial shear modulus $G_{0}$, and the red secant shear modulus $G$ ' when maximum shear stress is produced. It turned out that the lower the predominant frequency of input earthquake ground motion is, the larger the shear modulus of the ground tends to reduce. Next, the natural period of the wharf in turn resulted in the longer period when predominant frequency of the input earthquake ground motions are lower. This is because the smaller the shear modulus of the ground becomes, the longer the free length of the caisson foundation becomes. When predominant frequency of input earthquake ground motion was $0.2 \mathrm{~Hz}$ which greatly reduces the shear modulus of the ground, natural period of wharf in Case A was $0.81 \mathrm{~Hz}$, that in Case B $0.64 \mathrm{~Hz}$ and that in Case C $0.88 \mathrm{~Hz}$. By contrast, when predominant frequency of input earthquake ground motion was $2.0 \mathrm{~Hz}$ which only slightly reduces the shear modulus of the ground, natural period of wharf in Case A was $1.00 \mathrm{~Hz}$, that in Case B $1.47 \mathrm{~Hz}$ and that in Case C $0.96 \mathrm{~Hz}$. The result was that lower ground shear modulus will transfer natural period of wharf toward a lower frequency side by approximately $0.1-0.8 \mathrm{~Hz}$. Given small difference in the peak frequencies due to the difference in the points to evaluate spectral ratios, the natural periods of the wharf for each input earthquake ground motion were evaluated as the average of the three kinds of peak values. 

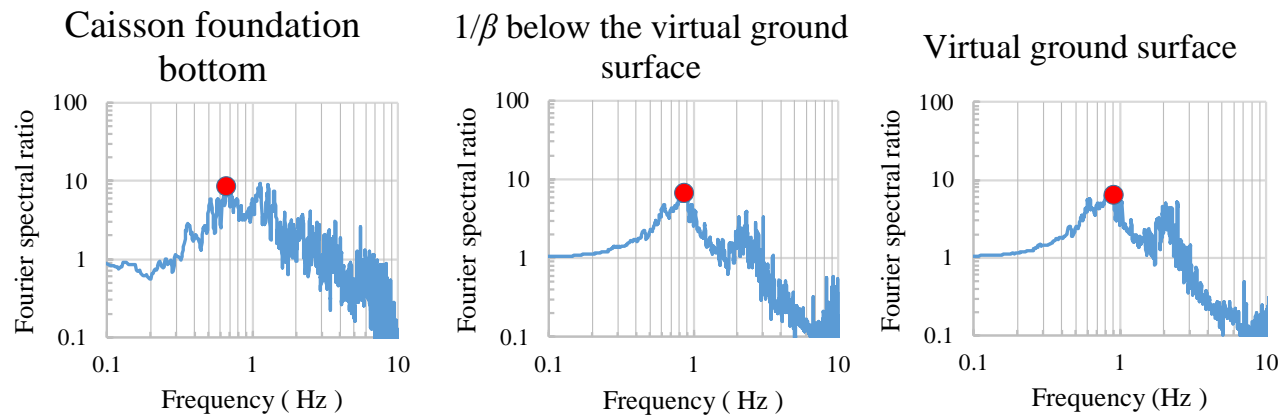

Figure 7: Fourier spectral ratio: Case A_0.2 Hz.

Table 7: Natural periods of wharves.

\begin{tabular}{|c|c|c|c|c|c|c|}
\hline \multirow{2}{*}{\multicolumn{2}{|c|}{$\begin{array}{l}\text { Examination } \\
\text { cases }\end{array}$}} & \multicolumn{4}{|c|}{ Peak frequency of spectral ratio $(\mathrm{Hz})$} & \multirow{3}{*}{\begin{tabular}{|c|}
$\begin{array}{c}\text { Natural } \\
\text { period } \\
(\mathrm{s})\end{array}$ \\
1.23 \\
\end{tabular}} \\
\hline & & \multirow{2}{*}{$\begin{array}{c}\frac{\text { Crown height of the wharf }}{\text { Virtual ground surface }} \\
0.67\end{array}$} & \multirow{2}{*}{$\begin{array}{c}\frac{\text { Crown height of the wharf }}{1 / \beta \text { below the virtual ground surface }} \\
0.88\end{array}$} & \multirow{2}{*}{$\begin{array}{c}\text { Crown height of the wharf } \\
\text { Bottom of the pile } \\
0.88\end{array}$} & \multirow{2}{*}{$\begin{array}{c}\text { Average } \\
0.81\end{array}$} & \\
\hline \multirow{3}{*}{ CaseA } & $0.2 \mathrm{~Hz}$ & & & & & \\
\hline & $1.0 \mathrm{~Hz}$ & 0.94 & 0.88 & 0.89 & 0.90 & 1.11 \\
\hline & $2.0 \mathrm{~Hz}$ & 1.08 & 0.96 & 0.97 & 1.00 & 1.00 \\
\hline \multirow{3}{*}{ CaseB } & $0.2 \mathrm{~Hz}$ & 0.69 & 0.62 & 0.62 & 0.64 & 1.55 \\
\hline & $1.0 \mathrm{~Hz}$ & 1.18 & 1.14 & 1.14 & 1.15 & 0.87 \\
\hline & $2.0 \mathrm{~Hz}$ & 1.68 & 1.37 & 1.37 & 1.47 & 0.68 \\
\hline \multirow{3}{*}{ CaseC } & $0.2 \mathrm{~Hz}$ & 0.96 & 0.84 & 0.83 & 0.88 & 1.14 \\
\hline & $1.0 \mathrm{~Hz}$ & 0.97 & 0.96 & 0.96 & 0.96 & 1.04 \\
\hline & $2.0 \mathrm{~Hz}$ & 0.96 & 0.96 & 0.96 & 0.96 & 1.04 \\
\hline
\end{tabular}

\subsection{Earthquake response of wharf}

This section will examine the appropriate positions for calculating the acceleration response spectra and the damping coefficient. Focusing on the time around which the horizontal displacement of the crown height of the wharf toward the sea side becomes the largest, the depth distribution of the response displacement between the sea side caisson foundation and ground in Case A is shown in Fig. 9. The response displacement distribution of caisson foundations at the respective time points "a" to "e" are roughly rectilinear and shows rocking centring round the caisson foundation bottom as the behaviour of rigid body. Namely, it can be said that the vibrations are not centring round the virtual fixed point as seen in the case of steel pipe pile foundation, but around the bottom of caisson foundations as the behaviour of a rigid body in case of a caisson foundation. In addition, these trends were likewise observed in Case B and Case C. Here, the caisson foundation bottom positions of the respective examination structures were: $1.35 / \beta$ below the virtual ground surface in Case $A, 1.14 / \beta$ (average of sea side caisson foundations and land side caisson foundations) below the virtual ground surface in Case B, and 1.54/ $\beta$ below the virtual ground surface in Case $\mathrm{C}$. In view that these are shorter than $3 / \beta$ - caisson foundation length assumed to be semi-infinite, short piles were conditioned accordingly. Since the wharves on steel pipe pile foundations have 


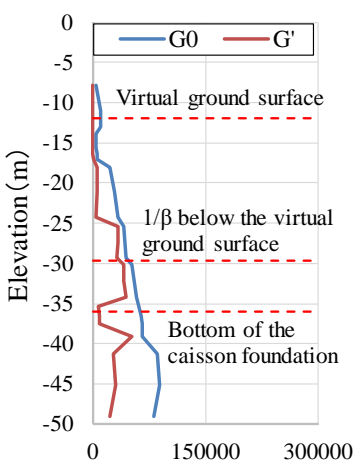

Shear modulus $\left(\mathrm{kN} / \mathrm{m}^{2}\right)$
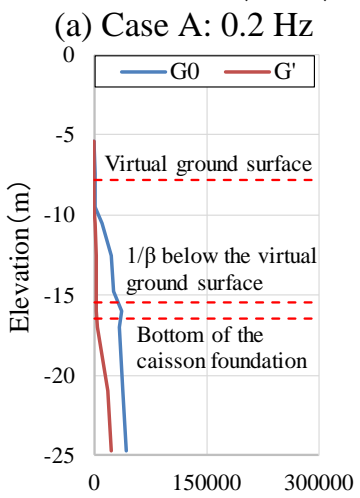

Shear modulus $\left(\mathrm{kN} / \mathrm{m}^{2}\right)$

(d) Case B: $0.2 \mathrm{~Hz}$

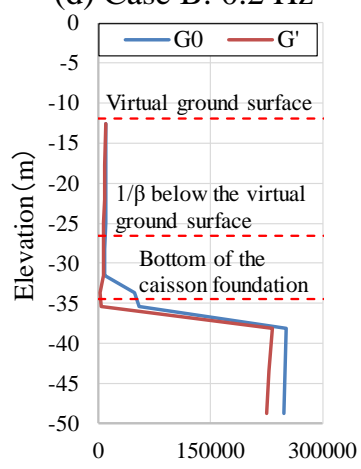

Shear modulus $\left(\mathrm{kN} / \mathrm{m}^{2}\right)$

(g) Case C: $0.2 \mathrm{~Hz}$

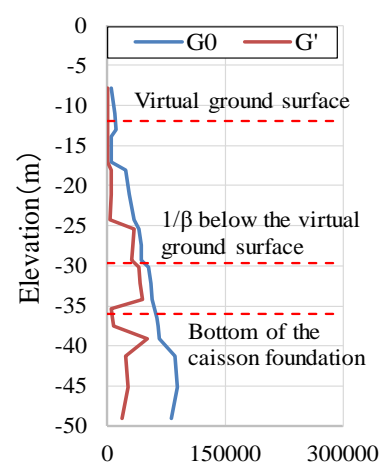

Shear modulus $\left(\mathrm{kN} / \mathrm{m}^{2}\right)$

(b) Case A: $1.0 \mathrm{~Hz}$

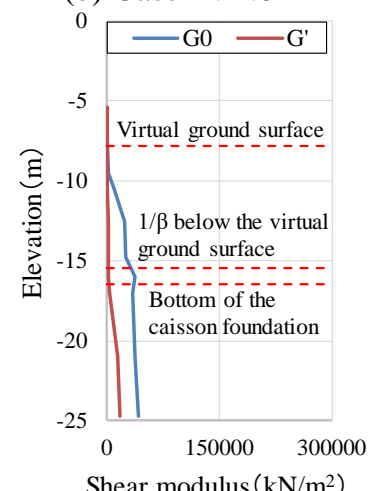

(e) Case B: $1.0 \mathrm{~Hz}$

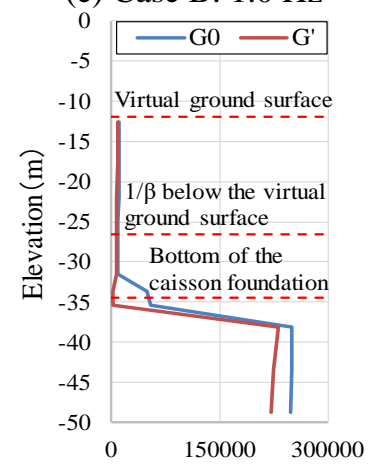

Shear modulus $\left(\mathrm{kN} / \mathrm{m}^{2}\right)$

(h) Case C: $1.0 \mathrm{~Hz}$

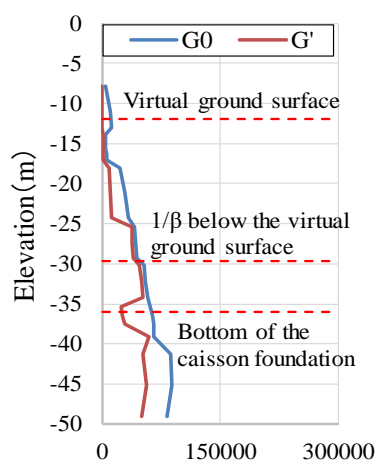

Shear modulus $\left(\mathrm{kN} / \mathrm{m}^{2}\right)$



Shear modulus $\left(\mathrm{kN} / \mathrm{m}^{2}\right)$

(f) Case B: $2.0 \mathrm{~Hz}$

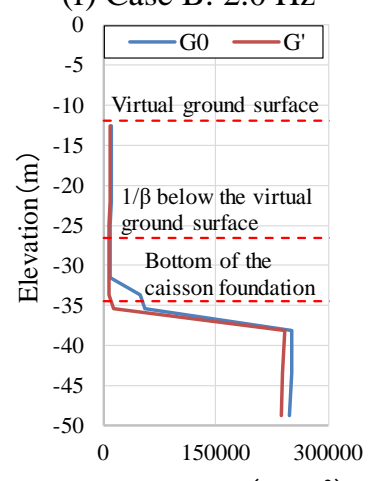

Shear modulus $\left(\mathrm{kN} / \mathrm{m}^{2}\right)$

(i) Case C: $2.0 \mathrm{~Hz}$

Figure 8: Distribution of shear modulus of the ground.

relatively smaller foundation rigidity than the wharves with pneumatic caisson foundations, and that the position of penetration depth is designed to be $3 / \beta$ below the virtual ground surface - pile length can be regarded as a semi-finite length, a concept that the virtual fixed point is the centre of the vibration relative to the ground holds good. In the case of the caisson foundation being examined in this research, however, the position of $1 / \beta$ below the virtual 

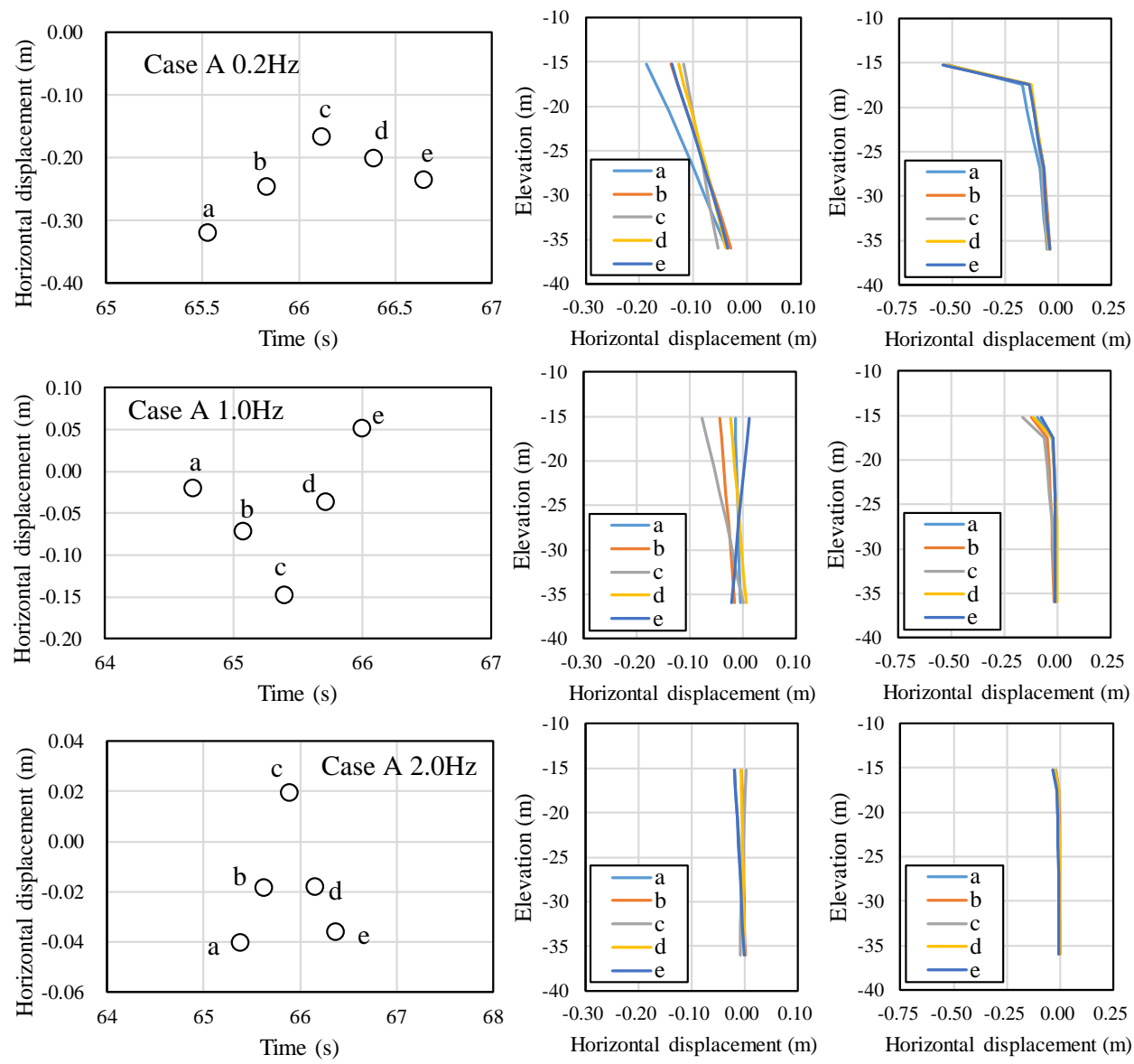

(i) Caisson foundation displacement

(ii) Ground displacement

Figure 9: Response displacement.

ground surface cannot be regarded as the fixed point. The above affirms that the position for calculating the acceleration response spectra that allow appropriate evaluation of the maximum value of response acceleration at the crown height of the wharf is the bottom of the caisson foundation.

Fig. 10 shows acceleration response spectra obtained through the two-dimensional analysis at the bottom level of the caisson foundation in the central part of the wharf. Here, red circles in these figures represent the maximum value of response acceleration of superstructure obtained through the two-dimensional analysis. Four kinds of damping constants, i.e. $5 \%, 10 \%, 15 \%$ and $20 \%$ were utilized at calculating the acceleration response spectra. This is because of having taken into account the possible necessity to set larger damping constants than those employed for ordinary structures in view that seismic behaviour in the central part of the wharf can be affected significantly by slopes and caisson foundations. Focusing on the relation between the maximum response acceleration obtained by the two-dimensional analysis and that by the acceleration response spectra corresponding to the respective damping constants, the maximum response acceleration by the two- 
dimensional analysis is smaller than that by the acceleration response spectra with the damping constant of $20 \%$ for Case B. On the contrary, acceleration of Case C turned out to be larger than the acceleration response spectra with the damping constant of $5 \%$. Case A resulted in acceleration response spectra with damping constant fluctuating between $5 \%$ and $20 \%$. Fig. 11 shows the errors sorted out by the damping constant of acceleration response spectra. Here, $\alpha 2$ is the maximum acceleration obtained from the two-dimensional analysis and $\alpha 1$ is that by the acceleration response spectra and those plotted in colour indicate average values. As the results, adequate damping constant is $5 \%$ for Case A and Case C. In Case B in turn the adequate damping constant was found to be $20 \%$. Focusing next on caisson foundation pitch, slope gradient and caisson foundation length of respective structures, caisson foundation pitch of Case A is $38 \mathrm{~m}$ and that of Case $\mathrm{C}$ is $30 \mathrm{~m}$ both in right angles to the face line, whereas that of Case B is as small as $14 \mathrm{~m}$. As regards the slope, Case A has a gradient of 1:3, and Case $C$ is flat, whereas Case $B$ has a steep slope of a 1:2 gradient. Furthermore, Case A and Case $C$ have uniform caisson foundation lengths on both sea and land sides, whereas in Case B the length on the sea side is longer than on the land side. Consequently, the effect in Case B of the difference in the response between the two sides becomes larger than in Case A and Case C, which presumably made it necessary to set the optimum damping constant at $20 \%$ which is larger than that for normal structures. The construction time of Case B is so old that if the concepts of current port facility standards are applied, resulting structural dimensions will highly likely have deviations from those shown in Fig. 2. On the basis of the foregoing results, the vibration centre of a pneumatic caisson foundation is at the bottom of caisson foundation, and hence the damping constant of a $5 \%$ level is considered to be enough as the damping of a structure.

\section{CONCLUSION}

In this study, seismic behaviour of a wharf with a pneumatic caisson foundation was discussed. The authors studied combination of the acceleration response evaluation positions as one part, and the damping constants as the other, combination which will yield an optimum reproducibility of the maximum response acceleration on the crown height of the wharf.


Figure 10: Acceleration response spectra at caisson foundation bottom. 

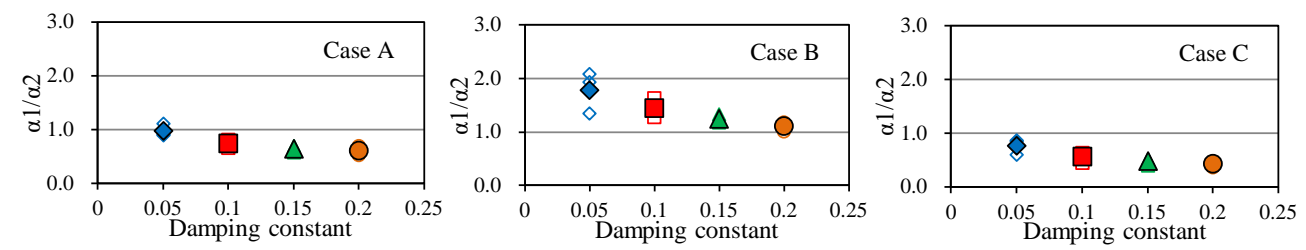

Figure 11: Relation between response acceleration calculation errors and damping (at caisson foundation bottom) (two-dimensional analysis).

Calculation of acceleration response spectra was conducted at: (1) the virtual ground surface; (2) $1 / \beta$ below the virtual ground surface; and (3) the bottom of the caisson foundation, where the two-dimensional nonlinear finite element analysis was used varying frequency characteristics of input earthquake ground motions and likewise varying damping constants into four kinds, i.e. 5\%,10\%,15\% and 20\%. Ultimately the differences with the wharf on steel pipe pile foundations were examined. The achievements of this study are summarized as follows:

1) When the response displacement distribution of the caisson foundation was arranged focusing on the time around which the response acceleration on the crown height of the wharf becomes the largest, the distribution turned out to be roughly rectilinear, and the vibrations were not centring round the virtual fixed point as seen in the case of steel pipe pile foundation, but around the bottom of caisson foundations as the behaviour of a rigid body in case of a caisson foundation.

2) On the basis of the evaluated natural period of the wharf, examination was conducted of the positions to evaluate response spectra and damping constants that allow an adequate assessment of the maximum response acceleration on the crown height of the wharf. The study revealed that the appropriate position to evaluate response spectra is the bottom end of the caisson foundation, and the damping constant is approximately $5 \%$, despite possible fluctuations depending on the conditions, and not $20 \%$ as in the case of a wharf with a steel pipe pile foundation.

\section{ACKNOWLEDGEMENT}

We express our deep gratitude for the favour of Dr. Masahiko Oishi of Oriental Shiraishi Co. Ltd. of having provided us with relevant data and valuable opinions during this research.

\section{REFERENCES}

[1] The Ports and Harbours Association of Japan, Technical Standards and Commentaries for Port and Harbour Facilities in Japan, 2007.

[2] Ishiguro, K. \& Takahashi, K., Crossbeam Solution Method for Piles and Sheet Piles under Horizontal Thrust, Sankaido Publishing Co. Ltd. (In Japanese.)

[3] Yokota, H., Takehana, N., Minami, K. \& Kawabata, N., A study on anti-earthquake design method for an open-type wharf on steel pipe piles. Journal of Structural Engineering, 44A, 1998. (In Japanese.)

[4] ASCE/SEI7-10 Minimum Design Loads for Buildings and Other Structures.

[5] Kuwabara, N. \& Nagao, T., A fundamental study on the evaluation of seismic coefficients for verification considering dynamic characteristics of a wharf on vertical piles. 65th Annual Meeting of Japan Society of Civil Engineers, 2010. (In Japanese.) 
[6] Okubo, Y., Kohama, E. \& Kusunoki, K., Comparisons of responses between opentype wharves on vertical piles by applying different verification methods. Journal of JSCE B3 (Ocean Development) of Japan Society of Civil Engineers, 68(2), 2012. (In Japanese.)

[7] Oishi, M., Nagao, T., Motegi, K., Ouchi, M., Sato, Y. \& Kiyomiya, O., A study on the seismic behaviour and verification method for earthquake performance of an opentype wharf with pneumatic caissons. Journal of JSCE A1 (Structural Engineering and Earthquake Engineering) of Japan Society of Civil Engineers, 68(4), 2012. (In Japanese.)

[8] Oishi, M., Nagao, T., Ouchi, M., Sato, Y. \& Kiyomiya, O., A study on the verification method for earthquake performance of an open-type wharf with pneumatic caissons. Journal of JSCE B3 (Ocean Development) of Japan Society of Civil Engineers, 69(2), 2013. (In Japanese.)

[9] Oishi, M., Ouchi, M. \& Nagao, T., Seismic coefficients for verification of an opentype wharf with pneumatic caissons at occurrence of level-one earthquake. 70th Annual Meeting of Japan Society of Civil Engineers, 2015. (In Japanese.)

[10] Iai, S., Matsunaga, Y. \& Kameoka, T., Strain space plasticity model for cyclic mobility. Soils and Foundations, 32(2), pp. 1-15, 1992.

[11] Towhata, I. \& Ishihara, K., Modelling soil behaviour under principal stress axes rotation. Proceedings of 5th International Conference on Num. Methods in Geomechanics, Nagoya, pp. 523-530, 1985.

[12] Hardin, B.O. \& Drnevich, V.P., Shear modulus and damping in soils: design equation and curves. J. of SM, ASCE, 98(SM7), pp. 667-692, 1972.

[13] Suetomi, I. \& Yoshida, N., Nonlinear behaviour of surface deposit during the 1995 Hyogoken-Nambu earthquake. Soils and Foundations, 11-22, Sep. 1998.

[14] Morita, T., Iai, S., Liu, H., Ichii, K. \& Sato, Y., Simplified Setting Method of Various Required Parameters in Prediction Program FLIP for Liquefaction-Damaged Structures. Documentary literature of Port and Harbour Research Institute, 1997. (In Japanese.)

[15] Ozutsumi, O., Tamari, Y., Oka, Y., Ichii, K., Iai, S. \& Umeki, Y., Modeling of interactions between piles and liquefied ground in two-dimensional effective stress analysis. 38rd Japan National Conference on Geotechnical Engineering, 2003. (In Japanese.)

[16] www.ysk.nilim.go.jp/kakubu/kouwan/sisetu/sisetu.html. 